\title{
Obituaries
}

Obituaries should be submitted by email to Kate Maynard at k.maynard@nature.com.

All submitted obituaries should be 350 words maximum in length (apart from obituaries for past presidents of the BDA

where the length should be 700-800 words).

Content of the obituary is down to the individual author, and the approval of the family should be given for the obituary prior

to submission to the $B D J$.

GEORGE FREDERICK KANTOROWICZ

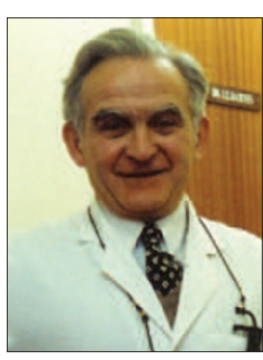

George was born in Bonn in 1921. His father was Jewish and Professor of Dentistry at Bonn Dental School. Leaving Nazi Germany in 1934 his father became Dean of Istanbul Dental School. George went to school there and excelled in gymnastics and swimming. He also took a BSc at Robert College.

As a young man he left Turkey for Palestine with two passports and the intention of joining the British Army. However, his plan backfired and he was arrested and spent some time in a Syrian jail.

Eventually George made it to Palestine where he joined the British Army although, because of his German background, his papers were stamped 'Not to be promoted beyond Corporal'. Despite this he was promoted to Sergeant in Austria and was 'mentioned in dispatches'. He served as a medical orderly across North Africa and Italy and as a multilingual interpreter, driver and general factotum in Austria.

After the war George went to Glasgow where he qualified as a dentist and where he met and married Hilda. He practised in Lichfield for a while and then moved to London where he started his own practice in Muswell Hill and later in Wimpole Street. He taught at the Royal Dental Hospital where he was appointed Consultant.

His teaching will be fondly remembered by several generations of students as vivacious, skilful, caring and with a great sense of humour. He was the main author of Inlays, crowns and bridges, first published in 1963 and revised for five editions over 30 years. It was the standard textbook on the subject in most dental schools in the UK.

A pioneering part of his career was his appointment to the Great Ormond Street Hospital for Children where he treated children with cleft lip and palate. This often involved extensive fixed bridges and splints.

George died on 16 November 2010 at the age of 89 . He is survived by his wife Hilda, his three children and six grandchildren.

LH, BGNS

\section{MICHAEL DEREK PROSSER}

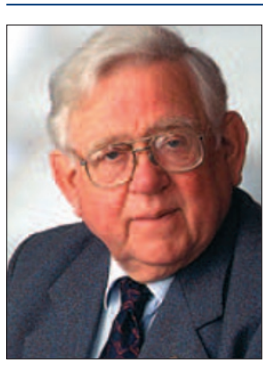

Unusual generosity and kindness characterised Mike Prosser's full and diverse life. Mike was an outstanding member of his profession.

Mike qualified at Bristol University in 1952. After a fouryear commission as a Royal Naval Dental Officer he entered general practice as an assistant to his father in Southgate in Bath, remaining a committed NHS general practitioner for his whole career.

Mike was the secretary of the Bristol and District Section of the BDA in the early 1960s and also membership secretary of the Western Counties Branch.

In 1973 he was elected to the Representative Board of the BDA, then to the GDSC. He served continuously in those influential bodies until 1990. Mike was courteous to all in lively debates, never known to use harsh words; at the same time he became a member of the Dental Estimates Board.

Mike was committed to team working so he strove to improve the conditions for DCPs through his membership of the Ancillary Personnel Committee and the Dental Technicians Education and Training Advisory Board. He was involved with LDCs, Executive Councils, FPCs and advisory bodies in the Bath area, chairing many of them.

He was elected Chairman of the Western Counties Branch Council in the late 1970s and President in 1981. His service to the BDA was accorded by the honour of Life Membership on his retirement.

Mike loved his chosen profession and one of his greatest joys was when his son, Andrew, who sadly predeceased him, qualified in dentistry. Three generations of the Prosser family qualified in dentistry.

Behind any successful man there must be family support. Jean always firmly supported Mike in their long and happy marriage. In retirement, both he and Jean continued to support patients in a practical way by being volunteers at the Royal United Hospital Bath.

Outside dentistry Mike was a Round Table member 1960-70 and later a Rotarian of some repute serving two terms as President of the Bath West Rotary Club. In 2002 he was awarded a Rotary International Citation. He was the Chairman of the Rotary Corneal Transplant Committee from 1994 until his death. Similarly he was the Chairman of the Royal Society of St. George from 1994.

We salute your memory, a full life, much lived in the service of others. You were one of the best colleagues we met in our practising lifetime.

$\mathrm{KM}, \mathrm{FAS}, \mathrm{AGM}$ 